\title{
Policy lessons of the East Asian demographic transition
}

Geoffrey McNicoll

Population Council

Follow this and additional works at: https://knowledgecommons.popcouncil.org/departments_sbsr-pgy

Part of the Demography, Population, and Ecology Commons, and the Quantitative, Qualitative, Comparative, and Historical Methodologies Commons

How does access to this work benefit you? Let us know!

\section{Recommended Citation}

McNicoll, Geoffrey. 2006. "Policy lessons of the East Asian demographic transition," Policy Research Division Working Paper no. 210. New York: Population Council. Version of record: https://doi.org/ 10.1111/j.1728-4457.2006.00103.x 


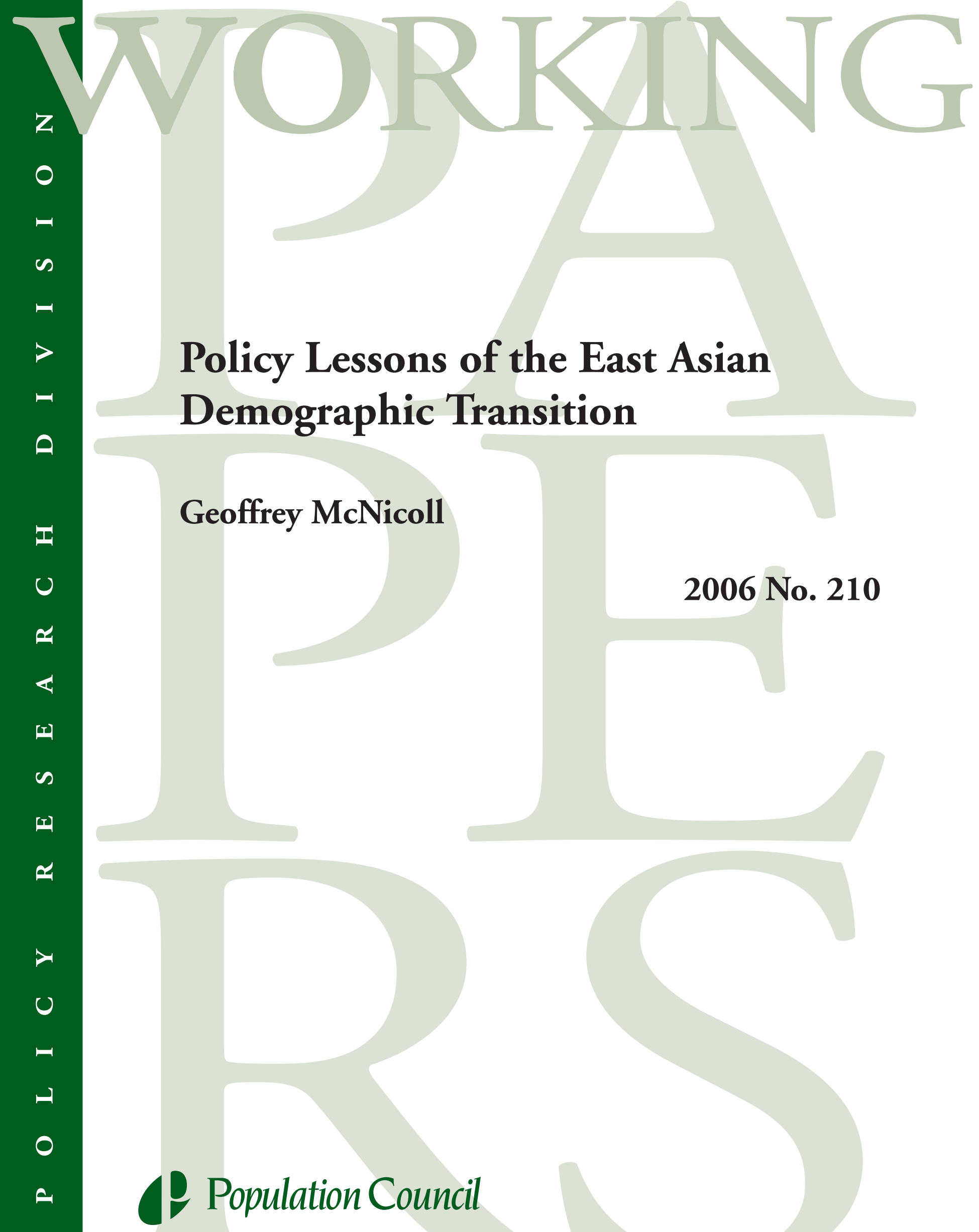




\section{(1) Population Council}

One Dag Hammarskjold Plaza

New York, New York 10017 USA

www.popcouncil.org

pubinfo@popcouncil.org

This material may not be reproduced without written permission from the author. For a list of Policy Research Division Working Papers, including those that are currently available for downloading in PDF format, see www.popcouncil.org/publications/wp/prd/rdwplist.html.

ISSN: $1554-8538$

(C) 2006 The Population Council, Inc. 


\title{
Policy Lessons of the East Asian Demographic Transition
}

\author{
Geoffrey McNicoll
}

Geoffrey McNicoll is Senior Associate, Policy Research Division, Population Council.

Acknowledgment: This work was supported by the Andrew W. Mellon Foundation and the William and Flora Hewlett Foundation.

An earlier version of the paper was presented at the XXV International Population Conference, Tours, July 2005. 


\begin{abstract}
The usual lessons drawn from East Asia's striking experience of health and fertility transition concern the efficacy of well-designed government programs catering to an existing or ideationally stimulated demand. An alternative interpretation sees the demographic change - and the uptake of services - as a byproduct of social and economic development together with, in some cases, strong government pressures. This paper probes more deeply into this experience, seeking to identify common features of development design and administration that underlay it and to derive lessons for policies elsewhere. The broad sequence entailed, initially, establishment of an effective, typically authoritarian, system of local administration, providing (sometimes incidentally) a framework for promotion and service delivery in health, education, and family planning. Subsequent economic liberalization offered new opportunities for upward mobilityand greater risks of backsliding - but along with erosion of social capital and the breakdown or privatization of service programs. The study is mainly focused on seven countries: Taiwan and South Korea ("tiger" economies), Thailand, Malaysia, and Indonesia ("second wave" countries), and China and Vietnam ("market-Leninist" economies). The period is roughly from the 1960s to the 1990s.
\end{abstract}


The "East Asian miracle" - the several decades of extraordinary economic growth and poverty reduction in a group of East and Southeast Asian countries, beginning around the 1960 s - provides the gold standard of development achievement. The miracle also entailed rapid social development, in particular the transformation of demographic regimes from high to low mortality and fertility and a strong expansion in secondary education on top of near-universal primary schooling. Altogether, through some combination of good judgment and historical luck those countries got the settings right. Others should seek to learn from them how it was done.

The miracle is identified in this paper with the development experience of seven countries: China, Indonesia, Malaysia, South Korea, Taiwan, Thailand, and Vietnam, roughly from the 1960s to the 1990s. Some regional high-flyers are thus omitted. Japan, whose industrialization and demographic transition were well underway before World War II, lies in a different time frame; Singapore and Hong Kong, although good for the averages, are too distinctive in their roles as city-states and entrepôt ports, far removed from the populous agrarian states that made up most of the region as it emerged from wartime occupation and decolonization. The Philippines would once have been routinely grouped with Thailand, Malaysia, and Indonesia, but its economic record-per capita income growth averaging 1 percent per year over 1965-1995-is no match for the others. (The Philippines is not one of the "high-performing Asian economies" that are the subject of the World Bank's much-cited report on the East Asian miracle-indeed it is hardly mentioned in it [World Bank 1993].) Table 1 presents the broad picture. ${ }^{1}$

Table 1: Economic growth and demographic transition in selected East Asian countries over a 30-year period

\begin{tabular}{|c|c|c|c|c|}
\hline Country & Period & $\begin{array}{l}\text { Av. annual growth } \\
\text { of GDP per capita } \\
\text { (percent) }\end{array}$ & $\begin{array}{l}\text { Increase in life } \\
\text { expectancy over } \\
\text { period (years) }\end{array}$ & $\begin{array}{l}\text { Change in total } \\
\text { fertility over period } \\
\text { (births per woman) }\end{array}$ \\
\hline \multicolumn{5}{|c|}{ The "tiger" economies } \\
\hline Taiwan & 1955-1985 & 6.2 & 11 & -4.6 \\
\hline South Korea & $1960-1990$ & 6.9 & 17 & -4.3 \\
\hline \multicolumn{5}{|c|}{ The second wave } \\
\hline Thailand & 1965-1995 & 5.4 & 10 & -4.2 \\
\hline Malaysia & 1965-1995 & 4.5 & 14 & -2.9 \\
\hline Indonesia & 1965-1995 & 4.1 & 19 & -2.8 \\
\hline \multicolumn{5}{|c|}{ "Market-Leninist" economies } \\
\hline China & $1970-2000$ & 4.9 & 9 & -4.1 \\
\hline Vietnam $^{c}$ & $1980-2000$ & 4.3 & 12 & -2.8 \\
\hline
\end{tabular}

a End points taken as averages of estimates for the two neighboring intervals.

b For the Philippines (1965-1995), the three right-hand columns would read 1.0 percent, 12 years, and -2.3 births.

c 20 year period.

Sources: economic data: Maddison (2003); demographic data: United Nations (2005) and endnote 7 (for China and Taiwan fertility). 
On the economic side, the ingredients of this success and what the policy lessons of the experience are, and are not, have been vigorously debated, especially in the shorthand terms of the relative significance of government and market. Some analysts assign the major determinative role to an interventionist state; others point to straightforward capital accumulation, physical and human, with a large role for private (including foreign direct) investment. The developmental state is pitted against the Washington consensus. ${ }^{2}$ There is no clear-cut victor: partisan declarations favoring one side often implicitly assume conditions, or borrow policy elements, characteristic of the other side, blurring the contrast. Reflecting this quasi-merger is the hybridized "postWashington consensus" strategy, with good governance a central feature and the hard edges of neoliberal economic orthodoxy softened by some concessions to managed trade and a social safety net.

In explaining population change there has been a parallel debate between government and market, but referring to the behavior of workers and consumers rather than that of firms and entrepreneurs. Here, one side stresses the importance of state interventions affecting family and individual norms, attitudes, and behavior, notably through schools and health and family planning programs; the other side sees individual and family aspirations (and fears) as the critical element, with changes in family economic conditions, opportunities, and expectations giving rise to greater demand for education and health services and smaller desired family size. The "programmers"- those emphasizing the effects of government provision of services - are pitted against the "economists," for whom increased demands for health and family planning services are effects of economic growth and the cultural change that accompanies it - effects likely to translate into lower mortality and fertility with or without government action.

This population debate was also intense for a time but lost urgency as the demographic transition progressed. With little seemingly hinging on the matter, the need for resolution weakened. A compromise position gained increasing support, one that gave a place to both service supply and demand factors. But since each had plausible effects on the other, there was considerable latitude in estimates of the balance between the two.

Compromise, however, is a poor grounding for policy action. For high-mortality, high-fertility countries elsewhere, what mattered was that the East Asian experience gave at least qualified endorsement to the effectiveness of public-sector service provision. For schools and health clinics, that was hardly necessary: these services, for the most part centrally funded and administered, were well-established instruments of social development-accepted as routine responsibilities of government. Family planning services could be seen as a straightforward, if novel, addition to the array. The three together, construed as population policy, provided a clear-cut agenda for government in promoting demographic transition.

The portrayal of programmatic success was marred in one respect in the case of family planning. Their accomplishments notwithstanding, the region's programs were faulted by some observers for being target-driven and in a number of instances unacceptably authoritarian in their dealings with their (largely female) clients. In the program models adapted for use elsewhere these features had to be corrected: 
authoritarian measures were to be firmly rejected, as was the whole notion of output targets; instead, programs were expected to emphasize service quality. This new perspective, endorsed in the 1994 Cairo Program of Action, shifted the fertility component of population policy away from what was portrayed as crude demographics and rebranded it as an aspect of women's reproductive health and freedom. Fertility decline could be achieved, even welcomed, but must not be blatantly intended. Implicit here was the presumption that the Asian success in fertility transition was not in part a product of that very authoritarianism.

Acceptance of a significant program role in fertility transition fitted well with another element of the consensus view of East Asian development. This was the positive feedback on economic growth that was held to derive from a rapid fertility decline, working through the additional resources for public and private investment freed up by a lowered child-dependency rate. Although long hypothesized on the basis of simple modeling, the relationship found supporting evidence only in the 1980s; since then it has attained the status of population-and-development orthodoxy, described in metaphor as a window of opportunity or a demographic gift or dividend. In some accounts it almost appears to be the lesson of the East Asian experience, economic and demographic: successful antinatalist measures provide a country with a limited period of low dependency during which it has the opportunity to ramp up investment; if it does not do so, the chance is lost. ${ }^{3}$

These are the terms in which East Asian development and demographic transition are generally understood, claimed to account (along with the good luck of a favorable external economic environment) for the region's remarkable performance. In looking for exportable lessons, however, broad prescriptions-increased investment, good governance, effective programs - even if well-founded, do not get us far; insights with policy substance must come from finer-grained levels of social reality. In the population case, what was it about the particular development paths that brought an early onset and rapid pace of demographic transition? Which government actions-institutional reforms, policies, programs - appear to have influenced outcomes at the grass-roots level, whether or not they were specifically aimed at demographic change, and through what means? How significant have been fortuitous historical circumstances, such as a country's institutional inheritance and the external economic and political environment? Such questions are taken up in this paper, with reference to the demographic transitions in the countries listed in Table 1.

My genre is casual empiricism, in the vein of what has been termed "forensic storytelling" (Lal and Myint 1996) or "analytic narrative" (Rodrik 2003). As with any discussion of historical change, outcomes are inherently overdetermined and the implicit counterfactuals used to call attention to particular lines of determination can always be contested. (If that were not the case, historians could deal once with a course of events, then pack up and leave.) My main focus is on rural society, demographically still dominant in the period of interest. The treatment is fairly schematic, skirting numerous complications - not least the matter of country heterogeneity. I roughly follow the two broad explanatory accounts mentioned above, looking first at the structural groundwork of social and administrative organization and the population-related programmatic efforts built on it, then at the process and effects of economic liberalization and expansion of 
mobility options. Necessarily my account relies heavily on the country-specific analyses of others.

\section{LOCAL ADMINISTRATION: SECURITY AND CONTROL}

The basic tasks of public administration in developing countries are maintaining social order and organizing public finance, especially revenue collection. Building on that minimalist administrative structure, governments accumulate a wide variety of programmatic responsibilities in areas linked to social and economic development - as well as some assigned to them by little more than simple expectation, as being tasks that governments nowadays, even poor ones, are meant to undertake. The administrative system is often used also in less productive ways, such as securing the government's own political survival - a function that may spill over into generalized suppression of dissent or of unwelcome reformist activity - and wielding its authority to exploit rent-seeking opportunities.

Administrative systems vary in the space they allow for local organizations to operate as entities more or less independent of government control—organizations such as farmers' cooperatives, irrigation societies, women's associations, and other interest groups with actual or potential political agendas. The state's promotion and mobilization of such groups can be a source of dynamism in rural development; independently initiated collective action, on the other hand, may be seen as a threat. The extent of government influence on local organizational freedom of action ranges widely among countries and across substantive areas, as documented for the 1960s in the mass of comparative data assembled by Uphoff and Esman (1974).

For the seven countries identified in Table 1, attainment of a stable and secure administrative order can be roughly located at the beginning of their respective miracle growth decades. The situations can be sketched very briefly as follows. ${ }^{4}$

In Taiwan and South Korea, the legacy from half a century of Japanese rule included a rural administrative system designed around the colonial priorities of stability and surplus extraction (chiefly rice), along with high rates of landlessness and tenancy. Security concerns were paramount for their post-World War II governments, facing threats of invasion - and actual invasion in the Korean case- but there was also an urgent need to boost food production. The radical land reforms of this period contributed on both scores, transforming the agricultural sector in a very few years (1947-50 in Korea, 1949-53 in Taiwan) from landlordism to owner-cultivation, a modern version of peasant proprietorship (Mason et al. 1980: 237-240, Koo 1968).

In Korea, a coercive state apparatus was put in place in the 1950s under the Syngman Rhee dictatorship, but its wielding in the cause of rural development came only with the Park government (initially a military junta) in 1961 and with the creation, in the same year, of the Economic Planning Board. The vigorous, village-based community development program known as Saemaul Undong (New Community Movement) was introduced in 1971, and soon put under the Home Affairs Ministry. The Saemaul movement combined hierarchical government influence with community mobilization 
around self-help initiatives, with the best-performing villages rewarded by the government. At its peak in the 1970s and 1980s it was an important instrument of social change. Unusually among community development efforts, it resisted capture by local elites. (Turner et al. 1993.)

In Taiwan, the mainlander KMT government imposed its authority down to the township level (an administrative unit averaging around 30,000 population) but ceded some political autonomy in local affairs to the majority indigenous Taiwanese through an elected local government, local assemblies, and farmers' associations (Burmeister et al. 2001). In the Uphoff-Esman study (1974: 29-30), Taiwan differed from Korea in the greater relative importance of local organizations in rural development and in allowing more upward as well as downward communication in the administrative hierarchy. Both countries scored high on an index of rural security (protection from violence, access to justice), but Taiwan ranked much higher on indicators of political participation (pp. 48, $56)$.

As in the tiger economies, security threats were also pervasive in postwar Malaysia, Thailand, and Indonesia - potential dominoes in the then plausible geopolitical scenario. In Malaysia, a sporadic Communist insurgency involving mostly rural ethnic Chinese petered out after independence (1957) and was declared ended in 1960, but the government's response (which included the forcible relocation of population in affected areas) left as a residue a strong civil administrative system backed by the sweeping police powers of the Internal Security Act. Rural development planning proved remarkably effective in this framework, notably in the close monitoring and comparative evaluation of development performance (Ness 1967). Government intrusiveness, however, did not extend to landownership and tenure issues. Under the New Economic Policy, in effect from 1971 to 1990, there was a major push to improve the conditions of rural Malays, a group that largely coincided with the smallholder class. Rudner (1983: 435) writes dryly of the "ethno-economic accounting" that evolved. The resettlement of landless people under the Federal Land Development Authority contributed to this objective.

In Thailand from the late 1950s and in Indonesia from the mid-1960s, a strong military presence in the countryside gave muscle to the civil administration, elevating the role of state over society and suppressing local political organization and dissent. In neither country was there redistribution of land, but nor was there an inherited pattern of large holdings. Although without a colonial administrative legacy to build on, Thailand's bureaucracy "which started out as a traditional Asiatic institution...steadily improved over the postwar decades to become one of the best outside East Asia" (Oshima 1993: 246). Observers describe the state's cooptation of village leadership, its "hierarchical and non-participatory mode of action," and its practices of social surveillance (Hirsch 1990: 228; Turton 1989: 66-67). Thailand took on the trappings of a developmental state: "Thai military leaders incorporated economic development as an integral part of their strategy to create stability and security" (Chai-Anan and Sukhumbhand 1993: 136). This was the setting in which the country's impressive rural development performance began.

In Indonesia in the 1950s and early 1960s the burgeoning Communist Party sought to organize the landless and land-poor into a radical agrarian movement, actions strongly opposed by other political forces, especially the Muslim parties, and by the 
army. The tensions grew and came to a head in the final, economically chaotic years of Sukarno's presidency, ending in 1965 with army-backed mass killings or imprisonment of Communist Party members and supporters. Over the next two years Suharto's militarized and technocratic New Order government emerged, enforcing political quiescence and firming up the regional civil administrative hierarchy. Not only was that hierarchy heavily seeded with retired officers and NCOs, but close lateral ties were established between it and a parallel military hierarchy at each level (province, district, subdistrict). Leavening what otherwise might have been a fairly grim regimen of militarized control, the government then used this system to pursue innovative agricultural extension activities and to direct resources into education and local public works. (Hansen 1973; McNicoll and Singarimbun 1983.)

In China, the administrative structure put in place after the Communist victory in 1949 reached down to villages with parallel and interlocked state and Party hierarchies of officials and cadres. Its Leninist trappings included both official and informal neighborhood surveillance, incessant meetings and indoctrination sessions, and household registration and restrictions on geographic mobility. However, establishment of a stable agrarian economy was continually deferred by the successive and increasingly radical reform efforts. A comprehensive land reform in 1950-52 was a kind of violent analogue to those of Korea and Taiwan, redistributing the holdings of landlords and rich peasants but leaving production decisions in the hands of households-albeit with increasing government intervention in marketing. Those changes might have given rise to a Korea-Taiwan-style smallholder farm sector, but any incipient stability on such a basis was disrupted by the collectivization measures of the mid-1950s, with the formation of village-level producer cooperatives and the suppression of most remaining private markets. In turn, this restructuring had barely gelled before the countryside was again roiled by further Maoist campaigns: communization in 1958 followed immediately by the Great Leap Forward, and, after recovery from the massive famine these produced, the Cultural Revolution in 1966. Stability of sorts returned as the Cultural Revolution ebbed in the early 1970s and many of the functions assumed by the communes devolved back to villages. The wholesale, though technically incomplete, retreat from collectivization came in the late 1970s under Deng Xiaoping's production responsibility system. The long and damaging Maoist detour finally yielded something close to a conventional East Asian-type landholding peasantry, with strong productivity incentives in place though beneath a still heavy-handed administration. The rural population, however, had in the meantime become two-thirds larger than in 1950. (Greenhalgh 1990; Lardy 1985.)

In Vietnam, the Communist regime in the North showed many formal similarities to China in Leninist administration, but the household economy was never as fully suppressed. Rural land reform began in the 1940s and collectivization (although with accounting units much smaller than China's communes) in the mid-1950s. After reunification in 1975, efforts were made to extend collectivization to the South. The resistance these encountered, their evident economic failure, and, no doubt, the precedent of China's reforms then underway soon led to a Dengist-style backtracking under the Second Five-Year Plan (1981-86), culminating in formal abandonment of collective farming throughout the country under the 1988 Land Law. As in China, privatization 
meant assignment of use-rights rather than formal ownership, leaving scope for rentseeking by local cadres. (Kerkvliet and Selden 1998; Ravallion and van de Walle 2001.)

In each of these seven cases, a period of political, social, and economic turbulence ended with the emergence of a comparatively stable rural social order with absent or curtailed landlordism and a measure of security of tenure. Legal ownership was still missing in the Communist states, but use-rights tended to solidify over time into de facto ownership, with holdings becoming heritable and rentable if not mortgageable. The emergent regimes were all authoritarian in varying degrees - China and Vietnam at one end of the range, Malaysia and Thailand at the other-and they showed varying paces of relaxation of government intrusiveness over time as agriculture lost its economic dominance, as urban labor markets expanded, and as consumer values spread. But in the security realm state control held firm, restricting political opposition and offering little if any scope for redress of claims against authority. Often, especially as they matured, the regimes sheltered a fair measure of arbitrariness, partiality, and corruption. Balanced against that, however, their pervasive presence and sheer muscularity probably served to deter uncountenanced crime against person and property. In comparison with much of the rest of the rural developing world, they contributed to an amelioration of the "environment of risk" - the term used by Mead Cain (1981), writing of South Asiaoffering comparative security of person and property and some predictability in relations with authority. In turn, these conditions enlarged the space for economic and demographic planning by families and individuals - albeit, in the Communist states, not until socialist policy failures set the stage for economic liberalization. Offsetting the gains for development, in a broader calculus, was a far less admirable record on human rights.

\section{SOCIAL INFRASTRUCTURE}

These systems of local public administration were largely the province of Interior Ministries, in several cases backed by a hierarchy of military or state-party functionaries (forming, in the phrase of one observer, an exoskeleton of command [Emmerson 1978: 83]). Such a framework delivers social and political orderliness - its immediate purpose - and serves as a structure through which to coordinate the program initiatives of other, functionally specialized, line ministries. A development-minded state is concerned to pursue such programs for their own sake, though no doubt also recognizing that broadbased development can help a government secure legitimacy and popular backingpolitical capital needed even by authoritarian regimes. From a demographic standpoint, the functional areas of chief proximate relevance are health services (especially preventive and primary health care) and family planning. Education of course also has a major demographic influence; but at the secondary level that is mostly relevant here, it is the expansion of demand rather than its characteristics as a program that warrants more attention.

Preventive health measures - vaccination, control of disease vectors, improved public hygiene and sanitation, and the like-could directly engage local government and draw on a state's administrative strengths. Immunization against childhood diseases became routine; environmental cleanups helped to lessen parasitic infections. China 
probably took these measures furthest, through its National Patriotic Health Campaign Committees working under central political direction (Jamison et al. 1984: 37). But in the other countries - and, of course, more widely in the developing world - similar, if less forcefully pursued, campaigns meshed well with the capabilities and top-down attitudes of officialdom. For health outcomes, preventive measures offered a high payoff.

All seven countries also had systems of health care nominally reaching out to villages, even if the distribution of actual clinics was sometimes sparse and the bias in favor of urban, hospital-based services was strong. China during the Maoist years was known for its extensive and innovative use of paramedics. Backed by an egalitarian ideology, having no awkward political dimension, and facing no weakness in demand, the numbers of "barefoot doctors" increased from around 100,000 in 1957 to 1.5 million by 1965 (Parish 1985: 6). Under the Cooperative Medical Scheme, which by the 1970s covered most of the rural sector, the financing of China's rural health system was substantially devolved to the village (brigade) level ( $\mathrm{Gu}$ and Tang 1995). The least effective rural health system of the seven countries was probably Indonesia's, where policies were set by a physician-dominated health ministry and implemented under largely indifferent Interior Ministry supervision. Fees from health center services made a significant contribution to local government revenues, but the expenditures that they financed went mainly to other activities such as public works (Achmad 1999: 171). Outside the Communist states, private health care services also played a significant role, especially pharmacies and midwives. Improving educational standards contributed to health outcomes by making for better nutrition, better hygiene, and more informed and more insistent client demands on service providers.

It is often assumed that family planning fits straightforwardly into the same "health-seeking" framework. In that view, demand for birth control—defined as demand at zero cost-already exists, openly or latently, and calls only for a minimally interventionist offer of (free) program services. That benignly therapeutic model, widely purveyed by international agencies, did not well describe many actual programs in East Asia. It came closest to doing so in the case of Taiwan, where the classic Taichung experiment of the early 1960s had imbued the national program with a wholly voluntaristic ethos (see Freedman and Takeshita 1969); ${ }^{5}$ Malaysia took a similar approach and soon discarded any antinatalist rationale for its activities (G. Jones 1990). But an authoritarian government was always likely to see a family planning program as one more development activity to which to apply its talents, resources, and operating habits. Quite likely, too, the potential clients of such a program - at the outset, villagers with limited scope for much exercise of individualism-would see the state's interest as not markedly more objectionable than many other government intrusions into daily life. On both sides, these inclinations departed from the prescriptions about reproductive rights spelled out in international conventions, but by and large they did not depart from them enough for that rights-based language to seem clearly belied. Only in the Communist states did official interference extend beyond the matter of contraceptive choice to actual fertility outcome. Korea, Indonesia, and China illustrate a progression of sorts in program intensity.

In Korea, family planning had been opposed by Syngman Rhee, but under his successor a major effort to introduce contraception was mounted under the First Five- 
Year Plan of 1962. The Planning Board defined the program as an economic measure and gave it high priority. Abortion too was made readily available, despite its being technically illegal until 1973. As with its other mass programs, the government approached the contraceptive program "much like a military campaign" with detailed targets and monitoring of performance. The Saemaul movement became involved, further mobilizing potential clients through mothers' clubs and other activities. Over time, however, "the growing demand for contraceptive services removed much of the need for coercion" (Mason et al. 1980: 387-390).

A somewhat similar story can be told for Indonesia. Family planning was one of the priorities of the New Order government, and moved into high gear in the 1970s. Leftwing opposition had been removed with the suppression of communism; right-wing opposition was deflected by skillful cooptation of Muslim political and religious leaders. Village officials, pressured to meet ambitious target numbers, were closely involved in recruiting program clients alongside staff of the Family Planning Board. While coercive tactics to gain acceptors were sometimes reported, so was enthusiastic participation by volunteer workers; moreover, the birth control methods purveyed by the program, unlike the case of China (and India), were reversible - abortion and sterilization were not a part - and the program measured its achievements by acceptance rates rather than birth rates. The details are well covered by Warwick (1986) and Hull and Hull (1997).

In China, client wishes in the matter were irrelevant. When state policy abruptly reversed itself in 1971 and declared that the birth rate must be brought down, an array of strong-arm measures was introduced in the form of the "later, longer, fewer" campaign. The same means that maintained political control-surveillance, indoctrination, sanction-were applied to regulate demographic behavior, and appeared to do so to remarkable effect, with fertility halved in less than ten years. Delayed marriage- the "later" part of the campaign - played a significant role, but so did abortion and sterilization in support of the other two parts. Then, in 1979, shifting to a still simpler demographic objective, the one-child policy was adopted. Overall, as Greenhalgh (1988: 661) puts it, the government created circumstances in which the political costs to families of noncompliance outweighed the economic costs. Increasingly over time, however, couples sought ways around the dictates - "forming alliances with birth planning cadres, having illicit births, manipulating registers" (ibid.) — options that widened greatly over time as the program came to make more use of economic penalties and as migration prohibitions lost force. ${ }^{6}$ A broadly similar but less stringent version of the Chinese approach - a two-child policy — was put in place in Vietnam (Goodkind 1995).

Did the programs work? Certainly they did in proximate terms. That is, the program supplies and services found users, and birth rates dropped rapidly. Less certain is the answer to the more significant question bearing on causation: what would have happened to birth rates in their absence? With negligible births outside marriage, a rising female age at marriage was a major factor in fertility decline throughout the region, a familiar byproduct of educational and labor force changes and the ongoing cultural shift away from arranged marriage. Aside from campaign rhetoric, marriage age was treated as an explicit part of the birth control program only in China. Within marriage, the demand for birth control would likely have been affected by rising expectations of child survival: mortality declines were already well underway in the 1960s and 1970s. But it is highly 
probable that the demand would have been met, though by less effective means, if the government's program had not been in the picture. Statistical efforts to investigate this counterfactual by separating out program effects from other plausible influences are notably unconvincing. Formal policy experiments, potentially more powerful, are rare: urban Taiwan (Taichung, mentioned above) and Matlab (rural Bangladesh) are the best known, the latter bearing most weight and showing distinct if modest impact. On the other hand, the programless but often rapid past fertility declines of many Western countries, or, nearer to hand, that of Burma, certainly do not suggest the necessity of organized family planning to bring about fertility transition. The familiar comparison between China and Taiwan does not even clearly confirm a stronger demographic effect of a coercive than a voluntary program: China's overall fertility trajectory, aside from plummeting and recovering during and immediately after the Great Leap years, roughly parallels the decline recorded in Taiwan — albeit at income levels far below Taiwan's. ${ }^{7}$

Nevertheless, most observers would probably agree that a strong-willed (if not strong-armed) and fairly competent administrative apparatus, promoting and delivering modern birth control methods, gave at least an initial impetus to fertility change. Many would also maintain that such an impetus would - and did-soon become redundant as burgeoning economic growth transformed the setting, creating new aspirations and opportunities. And by the 1990s, when the Cairo Agenda put target-based programs on the defensive, fertility transition in much of the region was already well on the way to completion.

\section{ASPIRATIONS AND OPPORTUNITY}

Studies of the East Asian economic miracle, however divergent in other respects, are agreed in emphasizing government roles in establishing conditions favoring investment. Primarily, the investment this proposition refers to is in production for export: manufacturing, mining, forestry, and plantation agriculture. ${ }^{8}$ In these sectors, "favorable conditions" entail satisfying a relatively small contingent of major players: domestic and foreign corporate leaders, entrepreneurs, and financial institutions. This concentration does not of course mean that what happens elsewhere in the economy and society is inconsequential, but it may lessen its importance in an accounting-type explanation of economic growth where there are other sources of investment funds besides the savings or taxes of households. Those other sources often existed. Thus, at crucial early stages of development, the high levels of US and Japanese investment in much of the region, initially in Korea and Taiwan, of revenues from rubber, tin, and palm-oil exports in Malaysia, of a surge of foreign assistance, the OPEC-linked windfall rise in oil rents, and logging exports in Indonesia, and of Japanese, Hong Kong, and Taiwanese investments in China were important parts of the East Asian story.

As dualistic growth theory teaches and as attested by much development experience, the smallholder agricultural sector can also be a major source of an investible surplus as productivity rises above subsistence levels. Attaining much-needed productivity gains in agriculture was a justification for the region's land reforms and for many subsequent extension programs. Fortuitously, these latter programs could draw on the new technology of the Green Revolution, which for rice saw its heyday in the 1970s 
with the distribution of newly developed high-yielding varieties and the complementary inputs of synthetic fertilizer and pesticides that they required. A more productive agriculture is likely to employ fewer workers, contributing to the reallocation of labor to other sectors.

For demographic change, it matters greatly how the agricultural surplus is extracted - whether, for instance, by forcible purchase at low prices (as in China) or directed through private-sector intermediaries (as in Taiwan). The method of extraction affects two factors of central importance for fertility and migration decisions: aspirations and opportunity. Thus, in the Taiwan case, the intersectoral financial linkage drew the rural population into the overall development equation: the relevant production and investment decisions for the economy were not merely those of a few key actors but of a legion of family enterprises and middlemen, now with newly expanded horizons. Forcible extraction, on the other hand, goes with continued low ambitions and expectations.

Aspirations for upward economic mobility (or, nearly equivalently, for avoidance of downward mobility) are near to being an innate human characteristic. Where they appear to be absent, the reasons can typically be traced to the authority structure of the surrounding society, which may routinely foreclose mobility opportunities - over time, perhaps, producing the kind of seeming passivity that was once taken as a hallmark of a peasantry. As decades of experience with rural development have shown, any such passivity quickly vanishes in the face of genuine options for economic improvement and favorable risk-return ratios.

The same kind of mobility aspirations can also be seen as the central force underlying fertility transition. This proposition has been entrenched in the demographic literature for more than a century. ${ }^{9}$ For modern-day East Asia the clearest analysis of the topic is contained in Susan Greenhalgh's treatment of fertility transitions in Sinic societies (China, Taiwan, Hong Kong, Singapore, and South Korea) - see Greenhalgh (1988). The relationship involved is not susceptible to formalization in the manner of Beckerian household economics, which relates how changing opportunities and prices facing the household elicit shifts in effort- and time-allocation among members, including adjustments that entail or lead to reductions in fertility. A transformation of family size intentions and behaviors does not require actual economic achievement, merely the existence of realistically accessible mobility paths. In those circumstances, motivation at the individual level can be taken for granted. Actual mobility may be impeded by any of a wide range of possible obstacles located in the surrounding society, ranging from pressures on the individual emanating from the family or local community to corrupt or capricious government. ${ }^{10}$

The most promising mobility paths in East Asian countries in this periodmodern sector employment-required education beyond the primary level (primary schooling was already becoming close to universal in the 1960s); for women, postponement of marriage - in particular, avoidance of early, arranged marriage; and, for most people, participation in the urban labor market.

The strong demand for secondary education is reflected in informal fee-based rationing in public systems and expansion of private schools. In Korea, private 
expenditures - mainly fees to private schools and items such as "voluntary" parental contributions to public schools - are estimated to have made up around two-thirds of total school expenditures over 1966-75 (Mason et al. 1980: 349-352). In 1970s Indonesia, achievement of mass elementary education shifted competition to high school entry, typically seen as a route to a hoped-for government job $(\mathrm{McNicoll}$ and Singarimbun 1983: 82). In post-Cultural Revolution China, the senior secondary level-noncompulsory - was the choke-point, demanding sizable fees. A growing private-school sector has provided a second-track option alongside the public schools. (Thøgersen 1987; Liang 2001.) In Vietnam, similarly, there has been a rapid expansion of semi-public and fully private secondary schools, with enrollment rationed by the costs to parents. By the 1990s, the state accounted for much less than half of all post-primary educational expenditures. (Nguyen 2002: 9-11.) For the seven countries, the enrollment outcomes are seen in Table 2: a doubling or more (in Indonesia, a trebling) in secondary enrollment as a proportion of the relevant age cohort in the period 1965-1980, and continuing if slower rises in later years. ${ }^{11}$ (Thailand, curiously, was a laggard on this score prior to the 1980s.) The gender imbalance against girls was steadily diminished over the period, almost disappearing in the 1990s (Knodel and Jones 1996).

Table 2. Proportion of age cohort enrolled in secondary schools, 1965, 1980, 1995, selected East Asian countries

\begin{tabular}{lrrr}
\hline Country & 1965 & 1980 & c. 1995 \\
\hline Taiwan & n.a. & 80 & 97 \\
South Korea & 35 & 76 & 96 \\
Thailand & 14 & 25 & 48 \\
Malaysia & 28 & 48 & 64 \\
Indonesia & 12 & 42 & 56 \\
China & 24 & 63 & 70 \\
Vietnam & n.a. & 47 & 55 \\
\hline
\end{tabular}

Sources: World Bank, World Development Report, various years; Asian Development Bank, Key Indicators, various years (Taiwan).

If parents saw secondary education as increasingly needed for their children - as a path to occupational security and status, even if job prospects were in fact slim (in the $1970 \mathrm{~s}$, further attenuated by the large relative size of the 1950s birth cohorts then entering the labor market) - and if schools were costly, even those that were nominally publicly funded, there was a strong incentive for parents to restrict their family size. For such a relationship, an exception to support if not to prove the rule is the Malaysian policy adopted in the 1970s to upgrade Malays' relative position in the economy vis à vis the ethnic Chinese by, among other measures, offering them generous educational benefits and opportunities for public-sector employment. Gavin Jones (1990) largely credits this policy with the stalling of Malaysia's fertility decline (a total fertility rate of 4 in the late 1980s, well above that of much poorer Indonesia), a phenomenon restricted to the Malays alone. 
Secondary schooling is inconsistent with very early marriage. Although this practice was much less prevalent in East than in South Asia, the proportions of women married in the age group 15-19 were relatively high in 1960s Malaysia and Indonesia. Between then and the 1980s, this proportion fell from 37 to 9 percent in Malaysia and from 40 to 19 percent in Indonesia (Leete and Alam 1993: 24).

For rural dwellers economic mobility often requires geographic movement: shortor long-term cityward migration or the commuting access to the urban labor market allowed by improving transport options. The first of these is captured in the census-based data on residence that underlie Table 3 . The time at which the rural population actually starts to diminish is determined by its rate of natural increase as well as by the pace of urban migration. The regional variation in this timing, shown in the column marked peak year, is striking, given the similarities in demographic transition experience across these countries. It occurred in the 1960s in Korea and Taiwan, in the 1990s in Malaysia, Indonesia, and China, and may not occur until after 2010 in Thailand and Vietnam.

Table 3. Rural population growth rates, $1960 \mathrm{~s}-1990 \mathrm{~s}$, peak year before (actual or projected) rural shrinkage, and average urban growth rate, selected East Asian countries

\begin{tabular}{|c|c|c|c|c|c|c|}
\hline \multirow[t]{2}{*}{ Country } & \multicolumn{4}{|c|}{ Rural growth rate (\% per year) } & \multirow{2}{*}{$\begin{array}{c}\text { Peak } \\
\text { year }\end{array}$} & \multirow{2}{*}{$\begin{array}{r}\text { Average urban } \\
\text { growth rate (\% per } \\
\text { year), } 1965-1995\end{array}$} \\
\hline & $1960 s$ & 1970s & $1980 \mathrm{~s}$ & 1990s & & \\
\hline Taiwan & 0.2 & -1.0 & -1.4 & n.a. & 1967 & 4.0 \\
\hline Sth Korea & 0.5 & -1.4 & -3.8 & -1.6 & 1967 & 4.5 \\
\hline Thailand & 2.9 & 1.7 & 1.3 & 0.9 & 2012 & 3.4 \\
\hline Malaysia & 1.9 & 1.0 & 1.1 & -0.2 & 1994 & 4.6 \\
\hline Indonesia & 1.9 & 1.6 & 0.7 & -0.4 & 1993 & 4.7 \\
\hline China & 2.2 & 1.6 & 0.4 & -0.2 & 1992 & $3.8^{\mathrm{a}}$ \\
\hline Vietnam & 2.0 & 2.0 & 2.1 & 1.2 & 2017 & $3.1^{b}$ \\
\hline
\end{tabular}

A heavily urban-biased economy or one characterized by enclave dualism with high-productivity and highly capitalized primary industries can show overall economic growth despite the existence of an impoverished rural population. In those circumstances migration is an obvious exit strategy for rural dwellers, who can move at least to the fringes of the cities to be in a position to make some claim on the urban economy. (A land frontier, where one still exists, is an alternative, if usually less popular, destination for outmigrants.) The resulting demographic transition is then essentially an urban phenomenon. It is not at all mysterious - there are straightforward, largely economic reasons for urban fertility and mortality to be low-but it is not what is distinctive about the East Asian transition. An urban-centered transition is closer to the stereotype of the Latin American case. ${ }^{12}$ 
The government administrative systems and the development programs they have supported are soon overtaken and sidelined in importance by changes in the wider economy and society. In much of the region, this happened smoothly as the private economy expanded into areas where government services had formerly been dominant. Free health services, free education, and free family planning were gradually replaced by fee-for-service, as marketization of the economy gained ground and as central governments found they could offload their former obligations on to regions, localities, or private citizens. (More pathological cases also involved out-of-control official rentseeking or corruption, although the main arenas for "crony capitalism" were the industrial and resource sectors.) But the effects of economic liberalization were more sharply felt in China and Vietnam. Public-sector health care systems were particularly vulnerable, showing rapid deterioration as market reforms spread. "In the early 1980s," Blumenthal \& Hsiao (2005) write, "China virtually dismantled its apparently successful health care and public health system overnight, putting nothing in its place." Health expenditures by the central government plummeted, leading to the widespread privatization of health care facilities; local-level risk pooling under the Cooperative Medical Scheme largely ceased (ibid.). In Vietnam, a recent report notes that "health services are increasingly delivered by a public 'shell' filled by 'private sector providers"' (Wescott 2003: 25).

\section{Distillation Of THE EAST Asian Transition EXPERIENCE}

The seven countries I have drawn my illustrations from are East Asia's prominent successes in development performance and demographic transition, aside from Japan and the city-states. The addition of China and Vietnam to the usual mix is important in pointing to the substantial commonalities in societal development that exist across the group beneath the obvious political contrasts. They do not of course exhaust the range of economic and demographic experience in the region, but together they portray East Asia's dynamism and characterize it to the rest of the world. ${ }^{13}$ In terms of demographic transition, the experience can be encapsulated in a short series of propositions.

Establishment of an effective system of public administration at the local level providing the rural population some assurance of physical security and predictability. The outlines of such a system are part of the institutional inheritance of any agrarian society, most commonly a tradition of authoritarian rule directed mainly at revenue collection. That legacy does not, of course, guarantee effectiveness, even for the limited aims of imposing political quiescence and extracting a surplus. Just as likely is an inheritance of pervasive insecurity deriving from corruption, social predation, and capricious administration, skewing the incentives facing families and harming productivity. ${ }^{14}$ Development- and security-minded East Asian governments, however, seized the opportunities for administrative renovation that opened in the aftermath of war or major civil unrest to firm up local government. Over time, rent-seeking by officialdom creeps back in, but the system plays a crucial role only for a comparatively short period-perhaps no more than a couple of decades.

Extremes of rural inequality, where they existed, are ameliorated by land reform. A de facto system of peasant proprietorship, even one at a kulak level with still-large numbers of landless workers, offers both the likelihood of social stability and, with appropriate 
knowledge and resource inputs, rapid productivity increases and enhanced savings. Land reform, however, may have mattered less for the gain in equity it produced (yielding the famous though politically innocent dictum of growth-with-equity to describe the East Asian economic model) than for removing a reactionary rural elite able to block change or capture new resource inputs. An important feature of the East Asian miracle economies, emphasized by Haggard (2004: 72), is the extent to which political elites enjoyed "political, organizational, and economic independence from private sector actors" in the early growth phase. (For Indonesia at least, that phase did not last long.)

The local administrative system is used to coordinate and give back-up support to the programmatic functions of line ministries, especially in the areas of health, education, and family planning. Service provision in health and education was initially strongly dirigiste, even if some of the funding for it was locally raised or fee-based. Demand for clinical health services can usually be taken for granted, but less so for preventive health measures. (Demand is irrelevant for many public health campaigns, which draw directly on administrative competence and may require little else.) Softness in the demand for education reflects the opportunity costs of child labor as well as some direct costs even when it is nominally free. And demand for family planning through a government program may be weak for any of a range of reasons, not least because of deficiencies in the services offered. In such cases local officials and community leaders can be drawn on to help with outreach, whether enforcement - as with vaccination campaigns - or with mobilizing a potential client base. Mobilization activities can easily and often do yield departures from the conventionally voluntaristic model of service delivery.

The spread or explicit adoption of market-oriented policies creates a starker and more competitive economic environment for families and individuals. Such an environment offers families and individuals greater opportunities for advancement and greater risks of downsliding. Social capital erodes as investment goes instead toward physical and human capital. As market forces spread into the public sector, extension services are financially squeezed. Formerly free or nearly free health services decay or are transformed into feefor-service arrangements. Similarly, the share of schooling costs borne by parents through formal and informal payments rises substantially, especially at the secondary and higher levels.

As new routes of economic mobility emerge, competition for places in secondary education intensifies, giving rise to formal and informal price rationing of access. Secondary and higher education are seen as increasingly necessary for modern-sector employment, for both sexes, creating a cost-squeeze on parents. A byproduct of these competitive pressures is a heightened demand for birth control. Improved educational outcomes yield further gains in health.

Expansion of the modern industrial and service economy and the urban informal economy, together with induced productivity gains in agriculture, generates a large-scale reallocation of labor out of agriculture and out of the rural sector. This is the standard pattern of dualistic economic growth. The rural population eventually starts to shrink, beginning earlier at young-adult ages. Increased public-sector transfers, such as infrastructure funding, private urban-to-rural remittances, and greater commuting access to the urban labor market gradually lessen the rural-urban economic divide and with it the 
rural-urban contrast in demographic patterns. Consumer goods and consumerist values and aspirations become widespread.

Positive feedbacks from lowered fertility include human capital deepening. The significance of the Coale-Hoover effect of fertility decline on savings may be questionable (at a minimum, hedged about with side-conditions), but smaller families are more certainly linked to health and educational benefits for children - thus to a deepening of human capital.

\section{QUALIFICATIONS AND RESERVATIONS}

In the discussion above I have not sought formal causal relationships-even if that were feasible on a subject of this nature. Rather, I have looked for commonalities of experience, whether in circumstances or policy design, that seem to characterize this significant episode in global demographic history. Those that I have pointed to cannot be claimed as either individually necessary or collectively sufficient in bringing about demographic transition, but are apparent contributors to it-and, as such, worth close attention in other situations.

In all seven countries some combination of security, educational opportunity, and mobility possibilities has been present, along with a significant and more-or-less authoritarian government role. Aside from the last element, that of course is not much different from the classical view of the factors behind demographic transition. But the new pattern is distinctive. Moreover, the sequence matters. Administrative order and effectiveness came first, with economic growth and social development emerging out of that setting, essentially by "getting institutions right." Neither the early statism nor the later liberalism seems to be dispensable: the first, if prolonged or excessively predatory, would stifle economic growth; the second, if alone, would yield a more disorderly and urban-centered transition. Government programs, in this interpretation, are part of the story but not its main thread. Administrative effectiveness transfers to programmatic effectiveness - programs that can engineer an early mortality reduction through public health and clinical extension services and that can promote birth control up to and sometimes beyond the demand for it.

Among the East Asian countries not in the Table 1 group, the most interesting contrasting case is the Philippines. Not quite a success - far from it by many economic criteria - it is also not at all a Burma-scale failure: it was, for instance, an early and impressive achiever in health and education. A study of the political economy of demographic change that compared the Philippines with Indonesia or Thailand would be enlightening. Plausibly, the same entrenched elite interests that slowed Philippine agrarian reform were responsible for the country's missing the manufacturing export opportunities that were seized so decisively by its neighbors. In its meshing of privatesector actors and political elites in this crucial period, the characteristic referred to above, the Philippines stands clearly apart from the Table 1 countries. Desultory economic performance in turn would account for the relatively slow pace of fertility decline (countrywide total fertility was still above 3.5 in the late $1990 \mathrm{~s}$ ). ${ }^{15}$ 
For the East Asian Communist states the conventional expectation, by no means assured, is that market Leninism will continue to evolve toward greater political freedom. Part of that trend would be recognition of an enlarged private sphere, with the state relinquishing the residual influence it has retained over demographic behavior, especially over total fertility. Freedom in this domain has some arbitrary features in the modern West (witness the debates over new reproductive technology, and even over marriage), and the evident societal interest in the size and upbringing of the next generation may see new efforts to influence outcomes. In China, although an eventual diminution in population size may not be unwelcome, a desire to limit the pace of decline might argue for retention of some direct public influence over fertility. And issues of sex selection and, more broadly, eugenic choice could further complicate the course of liberal evolution in this arena.

This raises the delicate matter of whether a lesson of the East Asian transition might be the limited importance of political freedom as a contributor to it. The proposition does not, of course, extend to the explicit coercion that has underlain the population policies of China and Vietnam, but does include the authoritarian approaches seen elsewhere in the region as economic development got underway. Rapid economic growth was attained, initially at least, in highly disciplined settings. Such settings do not ensure policy competence but might amplify it where it exists. Here they appeared to play a role in effective delivery of health, education, and family planning services. Democracy is not even necessarily good for poverty reduction, as evidenced by comparisons with, say, India or the Philippines. (The once-common India-China comparison, in which India is depicted as democratically muddling through but China is condemned for its Maoist disasters, sidesteps the more interesting counterfactual of an India that had an other-East Asian kind of polity from the time of independence.)

A related point is the absence of support East Asia's experience gives to the Cairo Agenda, notwithstanding that the darker aspects of that experience contributed to the gathering voices that produced the Cairo Plan of Action. East Asia's policies were essentially pre-Cairo: demographics were their raison d'être. Thus they cannot be adduced in support of the efficacy of a focus on reproductive rights: that came later and in one or two cases has yet to arrive. It is striking that the abandonment of demography at Cairo came just at the time when East Asia was beginning to be paraded, whether rightly or not, as a showcase for the power of a demographic dividend.

I have mentioned, but not made much of, fortuity: the accident of being in the right place, at the right time, and, perhaps also, with the right ancestry. Geography is a newly rediscovered factor in development thought - now drawn on, for example, to explain Africa's predicament. ${ }^{16}$ Clearly geopolitical circumstances - the Cold War, most evidently - contributed to East Asia's emergence as a dynamic economic region in the later twentieth century. The end of the Korean War, the suppression of Indonesia's Communist Party, and the North's victory in Vietnam each ushered in comparative political stability. Favorable commodity prices and trade expansion that did not encounter major barriers helped too.

Ancestry is a trickier matter. What has been inherited is most broadly described as culture. Demographers have not fared well in treating cultural explanation-when they 
do so, they attract the scorn of anthropologists. In development studies, "Asian values" is a culturalist term in heavy disfavor, a weak apologia for authoritarian rule that was advanced, often, by the rulers themselves. Caldwell (1993: 304) steps on this treacherous ground when he writes of family planning programs as "a manifestation-almost a cultural one - of the Asian arc from India through South-East Asia to China and South Korea." I have preferred to stick to administrative systems and to relations between the state and the individual-patterns that are also in some measure inherited, with some staying power and resilience, but with a comforting amount of tangibility, even if at base they too reflect culture.

\section{CONCLUDING REMARKS}

In retrospect, lost opportunities are easy to identify. The development experience of the East Asian states that found the right policy path earliest could have been mined for lessons to inform the others; cautionary tales of policy failure could similarly be transmitted. But that is not how the world works. Except in rare political circumstances a country cannot free itself from the legacy of past action, along with its ideological premises and the constituencies its action has elicited, to see problems afresh and contemplate radical policy overhaul. International agencies, providers of distilled policy experience, have analogous path-dependent constraints. So China's policy calamities and Indonesia's political impasse delayed serious development in those countries by a couple of decades, quite aside from the human suffering they brought. Further afield, Nehru's soft state and dirigiste policies yielded for several decades the notorious "Hindu rate of growth." These were not only lost years for energizing those economies but periods during which demographic expansion proceeded apace, environmental problems mounted, and the virtuous circles that accompany demographic transition remained unrealized.

There is some weariness in our profession with debates about demographic transition. They are seen as 1980s stuff, irrelevant for practical purposes now that fertility declines are underway almost everywhere. In terms of policy, the debates were supposedly settled by the Cairo consensus. But the East Asian experience still has much to offer other regions, beyond those elements of its family planning programs that found so much disfavor at Cairo. It has relevance especially for sub-Saharan Africa, where recent writing on the region's development problems is couched almost wholly in terms of development targets for 2015 and, perhaps in consequence, displays a striking absence of a discernible demographic dimension. Targets imply programs and programmatic thinking. While those have their place, I have argued that the more significant lessons of East Asia have to do with the effectiveness of public administration and the local opportunity structures that it fosters. Getting those local institutions right not only directly promotes demographic transition but has an important if ordinarily less-thanmiraculous economic payoff as well. 


\section{NOTES}

1 Miracles are time-limited. For Thailand and Indonesia, the period of rapid economic growth came to a sudden halt in the aftermath of the 1997 regional financial crisis, which affected those economies with particular severity. The recovery was slow, especially in the case of Indonesia. Note that while Maddison's (2003) income series (in "Geary-Khamis dollars"), drawn on in Table 1, are widely used in comparative analysis, they sometimes differ appreciably from the World Bank's purchasing-power-parity estimates. As a regional example, Maddison has Indonesia overtaking the Philippines in per capita GDP in the 1980s, falling back after 1997, but still ahead in 2000. World Bank estimates, in contrast, do not show the crossover and put Philippine income about 50 percent above Indonesia's in 2000 (World Development Indicators, various years).

2 Developmentalism, originally an interpretation of Japan's post-1945 experience with industrial policy, is now a term applied to countries as dissimilar as Brazil and Finland (Woo-Cumings 1999). The Washington consensus refers to the neoliberal economic policy "package" (trade liberalization, deregulation and privatization, fiscal policy discipline, flatter taxes, and the like), supposedly pushed on developing countries by the IMF and some other international agencies. The term has now often blurred into an antiglobalization cliché.

${ }^{3}$ For statements of (and reservations about) this argument, see, among other recent contributions, Mason et al. (1999).

${ }^{4}$ Part of the account referring to Indonesia and Thailand draws on material presented in McNicoll (1997).

5 The Taichung experiment demonstrated a substantial uptake of birth control methods proffered by fieldworkers in an urban setting with existing demand (and appreciable past use), and the power of social networks to spread information about those methods more widely.

${ }^{6}$ For an illuminating early-1990s case study of such negotiations, illustrating the increasing strength of "weapons of the weak" in circumventing birth planning dictates and the ambivalent role of village-level cadres, see Zhang (1999).

7 The total fertility rate trajectories are shown in the chart below (data sources: China: Banister [1987: 230]; Feeney and Yuan [1994: 387]; US Census Bureau's International Data Base. Taiwan: Department of Health statistics cited by Selya [2004: 133-134]):

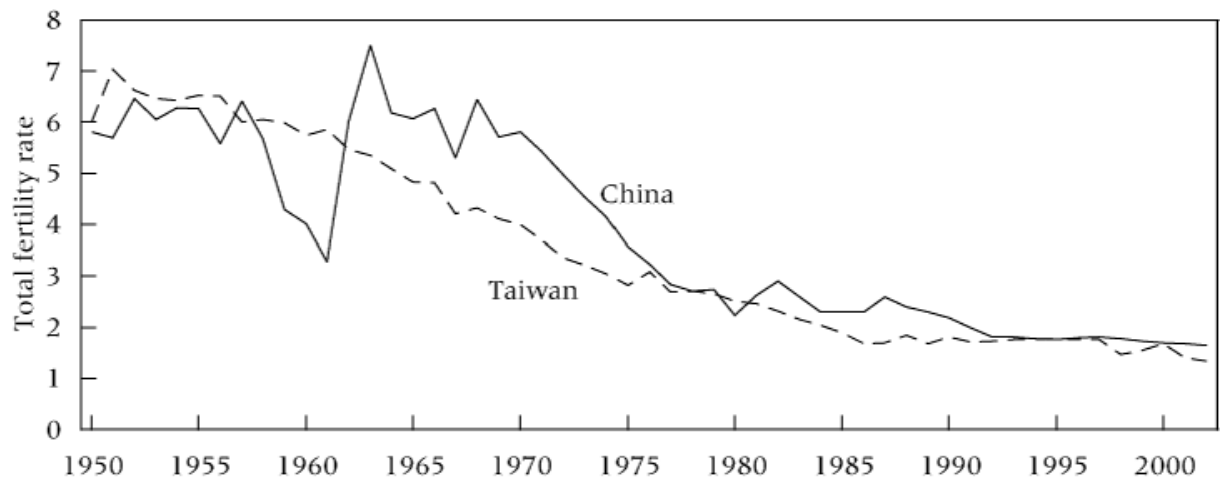

8 Productivity gains have contributed to the growth outcome along with capital accumulation, but the evidence from sources-of-growth decompositions suggests that the latter has dominated. The balance between the two remains a point of controversy: total factor productivity is played up by Bauer (2001), 
downplayed by Bhagwati (2000). The real miracle in East Asia, says Bhagwati (2000: 30), is "the phenomenal rise in private investment rates on a sustained basis."

9 See, for instance, the writings of John Billings, Arsène Dumont, Frank Fetter, E. A. Ross, and F. W. Taussig - all of them in the late nineteenth and early twentieth centuries - or, more recently, J. A. Banks and Judith Blake. (Excerpts from many of the relevant items have been reproduced in the Archives section of Population and Development Review.)

10 A forceful depiction of incipient development continually being snuffed out by predatory authority, drawing on diverse historical instances, is given by E. L. Jones (1988). For China itself, in the decade or so following the Cultural Revolution, what was initially a policy-driven fertility transition plausibly became a regime of entrenched low fertility governed largely by the mobility-fertility link. (The forcefulness of the one-child policy in its early years, however, suggests that the government believed that fertility was then below its "wanted" level.)

11 Enrollment data, mostly compiled by UNESCO, suffer major accuracy and comparability problems, so the figures in Table 2 should be taken as rough indicators only.

${ }^{12}$ At the onset of their fertility transitions, Brazil was over 50 percent urban, Colombia nearing 60 percent, and Mexico around 65 percent. The equivalent urban fractions for the Table 1 East Asian countries were in the range 15-30 percent. (United Nations 2005; Selya 2004: 83.)

${ }^{13}$ East Asia has its prominent failures too: Burma, which has shown decades of economic stagnation under both the soft-state rule of the "Burmese way to socialism" and the current military dictatorship; the distant laggards of Laos and Cambodia; and North Korea, a far outlier on almost any dimension of political economy. Such experience need not preclude fertility decline: according to the Population Division's time series (United Nations 2005), Burma's fertility roughly halved over 1970-2000; North Korea's, never high, was about 2.0 by 2000 . The case of the Philippines, a more instructive comparison than these, is discussed briefly below.

14 A competing source of security is sometimes to be found in kin- or patronage-based groupings. Typically with a fluid fringe-membership, these lack the formal accountability of corporate communities and local public administration but may act to subvert territorial social organization. (On the problem of kinship undermining territoriality — one that confronts many African states especially—see Hyden 1990.)

15 The Catholic Church's stance against birth control practice and programs, often invoked to explain the sluggish Philippine fertility transition, would arguably have been powerless in the face of rapid economic growth.

16 The Commission for Africa, in its report for the G-8 meeting in July 2005, boils down the drivers of development to "governance and geography" (Commission for Africa 2005: 215). 


\section{REFERENCES}

Achmad, Januar. 1999. Hollow Development: The Politics of Health in Soeharto's Indonesia. Demography Program, Australian National University.

Bauer, John. 2001. "Economic growth and policy in East Asia," in Andrew Mason (ed.) Population Change and Economic Development in East Asia: Challenges Met, Opportunities Seized. Stanford: Stanford University Press.

Bhagwati, Jagdish. 2000. The Wind of the Hundred Days: How Washington Mismanaged Globalization. Cambridge, MA: MIT Press.

Blumenthal, David and William Hsiao. 2005. "Privatization and its discontents - the evolving Chinese health care system," New England Journal of Medicine 353: 1165-1170.

Burmeister, Larry, Gustav Ranis, and Michael Young. 2001. "Group behavior and development: a comparison of farmers' organizations in South Korea and Taiwan." Economic Growth Center, Yale University, Discussion Paper 828.

Cain, Mead. 1981. "Risk and insurance: perspectives on fertility and agrarian change in India and Bangladesh," Population and Development Review 7: 435-474.

Caldwell, John C. 1993. "The Asian fertility revolution: its implications for transition theories," in Leete and Alam (1993).

Chai-Anan Samudavanija and Sukhumbhand Paribatra. 1993. "Thailand: liberalization without democracy," in James W. Morley (ed.) Driven by Growth: Political Change in the AsiaPacific Region. Armonk, NY: Sharpe.

Commission for Africa. 2005. Our Common Interest: Report of the Commission for Africa. [London].

Emmerson, Donald K. 1978. "The bureaucracy in political context: weakness in strength," in Karl D. Jackson and Lucien W. Pye (eds.) Political Power and Communication in Indonesia. Berkeley: University of California Press.

Feeney, Griffith and Yuan Jianhua. 1994. "Below replacement fertility in China? A close look at recent evidence," Population Studies 48: 381-394.

Freedman Ronald and John Y. Takeshita. 1969. Family Planning in Taiwan: An Experiment in Social Change. Princeton: Princeton University Press.

Goodkind, Daniel M. 1995. "Vietnam's one-or-two-child policy in action," Population and Development Review 21: 85-111.

Greenhalgh, Susan. 1988. "Fertility as mobility: Sinic transitions," Population and Development Review 14: 629-674.

Greenhalgh, Susan. 1990. "Land reform and family entrepreneurship in East Asia," in Geoffrey McNicoll and Mead Cain (eds.) Rural Development and Population: Institutions and 
Policy. Supplement to Population and Development Review, vol. 15. New York: Oxford University Press.

$\mathrm{Gu}$ Xing-Yuan and Tang Sheng-Lan. 1995. "Reform of the Chinese health care financing system," in Peter Berman (ed.) Health Sector Reform in Developing Countries: Making Health Development Sustainable. Boston: Harvard School of Public Health.

Haggard, Stephan. 2004. "Institutions and growth in East Asia," Studies in Comparative International Development 38 (4): 53-83.

Hansen, Gary E. 1973. The Politics and Administration of Rural Development in Indonesia: The Case of Agriculture. Berkeley: Center for South and Southeast Asia Studies, University of California. (Research Monograph No. 9.)

Hirsch, Philip. 1990. Development Dilemmas in Rural Thailand. Singapore: Oxford University Press.

Hull, Terence J. and Valerie J. Hull. 1997. "Politics, culture, and fertility transitions in Indonesia," in Gavin W. Jones et al. (eds.), The Continuing Demographic Transition. Oxford: Clarendon Press.

Hyden, Goran. 1990. "Local governance and economic-demographic transition in rural Africa," in G. McNicoll and M. Cain (eds.) Rural Development and Population: Institutions and Policy. New York: Oxford University Press.

Jamison, Dean T., et al. 1984. China: The Health Sector. Washington, D.C.: World Bank.

Jones, E.L. 1988. Growth Recurring: Economic Change in World History. New York: Oxford University Press.

Jones, Gavin W. 1990. "Fertility transitions among Malay populations of Southeast Asia: puzzles of interpretation," Population and Development Review 16 (3): 507-537.

Kerkvliet, Benedict J. Tria and Mark Selden. 1998. "Agrarian transformations in China and Vietnam," China Journal 40 (Special Issue): 37-58.

Knodel, John and Gavin W. Jones. 1996. "Post-Cairo population policy: does promoting girls' schooling miss the mark?" Population and Development Review 22: 683-702.

Koo, Anthony Y. C. 1968. The Role of Land Reform in Economic Development-A Case Study of Taiwan. New York: Praeger.

Lal, Deepak and H. Myint. 1996. The Political Economy of Poverty, Equity, and Growth: A Comparative Study. Oxford: Clarendon Press.

Lardy, Nicholas. 1985. "State intervention and peasant opportunities," in William L. Parish (ed.) Chinese Rural Development: The Great Transformation. Armonk, NY: Sharpe.

Leete, Richard and Iqbal Alam (eds.) 1993. The Revolution in Asian Fertility: Dimensions, Causes, and Implications. Oxford: Clarendon Press. 
Liang, Xiaoyan. 2001. "China: challenges of secondary education." Working Paper, Human Development Network, World Bank. (Secondary Education Series)

Maddison, Angus. 2003. The World Economy: Historical Statistics. Paris: Organisation for Economic Co-operation and Development.

Mason, Andrew, Thomas Merrick, and R. Paul Shaw (eds.). 1999. Population Economics, Demographic Transition, and Development: Research and Policy Implications. Washington, D.C.: World Bank.

Mason, Edward S. et al. 1980. The Economic and Social Modernization of the Republic of Korea. Council on East Asian Studies, Harvard University.

McNicoll, Geoffrey. 1997. "The governance of fertility transition: reflections on the Asian experience," in Gavin W. Jones et al. (eds.) The Continuing Demographic Transition Oxford: Clarendon Press.

McNicoll, Geoffrey and Masri Singarimbun.1983. Fertility Decline in Indonesia: Analysis and Interpretation. Washington, DC: National Academy Press.

Ness, Gayl D. 1967. Bureaucracy and Rural Development in Malaysia. Berkeley: University of California Press.

Nguyen, Nga Nguyet. 2002. "[Vietnam:] Trends in the education sector from 1993-98," World Bank Policy Research Working Paper No. 2891.

Oshima, Harry T. 1993. Strategic Processes in Monsoon Asia's Economic Development. Baltimore, MD: Johns Hopkins University Press.

Parish, William L. 1985. Chinese Rural Development: The Great Transformation. Armonk, NY: Sharpe.

Ravallion, Martin and Dominique van de Walle. 2001. "Breaking up the collective farm: welfare outcomes of Vietnam's massive land privatization." Development Research Group, World Bank. (Policy Research Working Paper 2750.)

Rodrik, Dani (ed.) 2003. In Search of Prosperity: Analytic Narratives on Economic Growth. Princeton: Princeton University Press.

Rudner, Martin. 1983. "Changing planning perspectives of agricultural development in Malaysia," Modern Asian Studies 17: 413-435.

Selya, Roger Mark. 2004. Development and Demographic Change in Taiwan. Singapore: World Scientific.

Thøgersen, Stig. 1987. "China's senior middle schools in a social perspective: a survey of Yantai district, Shandong province," China Quarterly 109: 72-100.

Turner, John E., Vicki L. Hesli, Dong Suh Bark, and Hoon Yu. 1993. Villages Astir: Community Development, Tradition, and Change in Korea. Westport, CT: Praeger. 
Turton, Andrew. 1989. "Thailand: agrarian bases of state power," in Gillian Hart et al. (eds.) Agrarian Transformations: Local Processes and the State in Southeast Asia. Berkeley: University of California Press.

United Nations. 2005. World Population Prospects: The 2004 Revision-Population Database. http://esa.un.org/unpp.

Uphoff, Norman T. and Milton J. Esman. 1974. Local Organization for Rural Development: Analysis of Asian Experience. Ithaca: Rural Development Committee, Center for International Studies, Cornell University.

Warwick, Donald P. 1986. "The Indonesian family planning program: government influence and client choice," Population and Development Review 12: 453-490.

Wescott, Clay G. 2003. "Hierarchies, networks, and local government in Viet Nam," International Public Management Review 4, no. 2: 20-40.

Woo-Cumings, Meredith (ed.). 1999. The Developmental State. Ithaca: Cornell University Press.

World Bank. 1993. The East Asian Miracle: Economic Growth and Public Policy. New York: Oxford University Press for the World Bank.

Zhang Weiguo. 1999. "Implementation of state family planning programmes in a northern Chinese village," China Quarterly 157: 202-230. 


\section{POLICY RESEARCH DIVISION WORKING PAPERS}

If still in print, single copies of up to three working papers from 1989 through 2003 are available free of charge.

Beginning with the 2004 issues, working papers are no longer available in print format. Instead they are distributed electronically. As each new paper is completed subscribers are notified by e-mail and a link to the paper is provided.

To subscribe to the Policy Research Division working paper e-mail notification list, or to obtain back issues from 1989 to 2003, please send your request to prdwp@popcouncil.org. PDFs of recent issues are available at www.popcouncil.org/publications/wp/prd/rdwplist.html

2006

210 Geoffrey McNicoll, "Policy lessons of the East Asian demographic transition."

209 Cynthia B. Lloyd, Cem Mete, and Monica J. Grant, "The implications of changing educational and family circumstances for children's grade progression in rural Pakistan: 1997-2004.”

\section{5}

208 James F. Phillips, Ayaga A. Bawah, and Fred N. Binka, "Accelerating reproductive and child health program development: The Navrongo Initiative in Ghana."

207 John Bongaarts and Griffith Feeney, "The quantum and tempo of life-cycle events."

206 Barbara S. Mensch, Monica J. Grant, and Ann K. Blanc, "The changing context of sexual initiation in sub-Saharan Africa."

205 Geoffrey McNicoll, "Population and sustainability."
204 John Bongaarts, "The causes of stalling fertility transitions."

203 Ayaga A. Bawah and Fred N. Binka, "How many years of life could be saved if malaria were eliminated from a hyperendemic area of northern Ghana?"

202 Barbara S. Mensch, Susheela Singh, and John B. Casterline, "Trends in the timing of first marriage among men and women in the developing world."

201 Zachary Zimmer, "Active life expectancy and functional limitations among older Cambodians: Results from a 2004 survey."

200 Brian Wells Pence, Philomena Nyarko, James F. Phillips, and Cornelius Debpuur, "The effect of community nurses and health volunteers on child mortality: The Navrongo Community Health and Family Planning Project."

199 Zachary Zimmer, Linda G. Martin, Mary Beth Ofstedal, and Yi-Li Chuang, "Education of adult children and mortality of their elderly parents in Taiwan." 
198 Mian Bazle Hossain, James F. Phillips, and Thomas K. LeGrand, "The impact of childhood mortality on fertility in six rural thanas of Bangladesh."

197 Kristine R. Baker, Mary Beth Ofstedal, Zachary Zimmer, Zhe Tang, and Yi-Li Chuang, "Reciprocal effects of health and economic well-being among older adults in Taiwan and Beijing."

196 Mark R. Montgomery and Paul C. Hewett, "Poverty and children's schooling in urban and rural Senegal."

2004

195 Luciana Suran, Sajeda Amin, Lopita Huq, and Kobita Chowdury, "Does dowry improve life for brides? A test of the bequest theory of dowry in rural Bangadesh."

194 Barbara S. Mensch, Monica J. Grant, Mary P. Sebastian, Paul C. Hewett, and Dale Huntington. "The effect of a livelihoods intervention in an urban slum in India: Do vocational counseling and training alter the attitudes and behavior of adolescent girls?"

193 Amanda Ritchie, Cynthia B. Lloyd, and Monica Grant. "Gender differences in time use among adolescents in developing countries: Implications of rising school enrollment rates."

192 John Bongaarts. "Long-range trends in adult mortality: Models and projection methods."
John Koku Awoonor-Williams, Ellie S. Feinglass, Rachel Tobey, Maya N. Vaughan-Smith, Frank K. Nyonator, Tanya C. Jones, and James F. Phillips, "Bridging the gap between evidence-based innovation and national healthsector reform in Ghana."

190 Kelly Hallman, "Socioeconomic disadvantage and unsafe sexual behaviors among young women and men in South Africa."

Toshiko Kaneda, Zachary

Zimmer, and Zhe Tang, "Differentials in life expectancy and active life expectancy by socioeconomic status among older adults in Beijing."

188 Cynthia B. Lloyd and Monica J. Grant, "Growing up in Pakistan: The separate experiences of males and females."

187 Zachary Zimmer, Xianghua Fang, Toshiko Kaneda, Zhe Tang, and Julia Kwong. "Trends and transitions in children's coresidence with older adults in Beijing municipality."

186 Sajeda Amin and Alaka M. Basu. "Popular perceptions of emerging influences on mortality and longevity in Bangladesh and West Bengal."

185 John Bongaarts. "Population aging and the rising cost of public pensions."

184 Mark R. Montgomery and Paul C. Hewett. "Urban poverty and health in developing countries: Household and neighborhood effects." 